\title{
Main Qualifications Required for Employment of Recreation Experts: The Perspective of Sector Representatives*
}

\author{
Kerem Yıldırım ŞİMŞEK ${ }^{1}$
}

\author{
Hüseyin ÇEVIK'
}

\author{
Anıl Onur MERCANOĞLU ${ }^{3}$
}

\begin{abstract}
Recreation experts are employed in public institutions at a very limited level. Employment limitations in the public institutions direct the graduates of the recreation department to the private sector. This situation necessitates that the qualifications of the recreation department graduates must coincide with the characteristics that the private sector sought in the recreation expert. In line with this requirement, the aim of the research is to determine the basic characteristics required of the recreation department graduates to be employed in the recreation industry in Turkey. In the study, semi-structured interviews were conducted with the 9 participants who were determined by the criterion sampling method. The research group consists of senior managers of businesses that provide sports recreation, tourism recreation, shopping recreation, park recreation, adventure recreation and outdoor recreation services with a high number of employment. Content analysis, one of the qualitative data analysis methods, was conducted on the data obtained as a result of the interviews. When the research findings are examined, it is seen that the characteristics sought in recreation graduates are gathered under five sub-themes. The resulting features can be used as a guide in the recomposition of training programs and in the employment processes. In this study, suggestions are presented on the basic characteristics of recreation department graduates needed in industry and the development of recreation department education programs.
\end{abstract}

Keywords: Employment, Recreation Expert, Recreation Industry

\section{Rekreasyon Uzmanlarının İstihdamı İçin Gerekli Temel Nitelikler: Sektör Temsilcilerinin Bakış Açısı}

\section{$\ddot{O} z$}

Kamu kurumlarında rekreasyon uzmanları çok sınırlı düzeyde istihdam edilmektedir. Kamu kurumlarında istihdam kısıtlamaları rekreasyon bölümü mezunlarını özel sektöre yönlendirmektedir. Bu durum rekreasyon bölümü mezunlarının niteliklerinin özel sektörün rekreasyon uzmanında aradığı özelliklerle örtüşmesini gerektirmektedir. Bu gereklilik doğrultusunda araştırmanın amacı, Türkiye'de rekreasyon sektöründe istihdam edilecek rekreasyon bölümü mezunlarında aranan temel özellikleri belirlemektir. Araştırmada ölçüt örnekleme yöntemi ile belirlenen 9 katılımcıyla yarı yapılandırılmış görüşme gerçekleştirilmiştir. Araştırma grubu; spor rekreasyonu, turizm rekreasyonu, alışveriş rekreasyonu, park rekreasyonu, macera rekreasyonu ve açık hava rekreasyonu hizmetleri veren ve istihdam oranı yüksek işletmelerin üst düzey yöneticilerinden oluşmaktadır. Görüşmeler sonucunda elde edilen veriler üzerinde nitel veri analizi yöntemlerinden içerik analizi yapılmıştır. Araştırma bulguları incelendiğinde rekreasyon mezunlarında aranan özelliklerin beş alt tema altında toplandığı görülmektedir. Ortaya çıkan özellikler, eğitim programlarının yeniden düzenlenmesinde ve istihdam süreçlerinde bir rehber olarak kullanılabilir. Bu çalışmada rekreasyon bölümü mezunlarının endüstride ihtiyaç duyulan temel özellikleri ve rekreasyon bölümü eğitim programlarının geliştirilmesi konusunda öneriler sunulmuştur.

Anahtar Kelimeler: İstihdam, rekreasyon uzman1, rekreasyon endüstrisi

\footnotetext{
*This study was supported under the project number 11408S369, which was accepted by the Anatolian University Scientific Research Projects Commission.

${ }^{1}$ Eskişehir Technical University, Faculty of Sports Science, Eskişehir-Turkey, e-posta:keremys@eskisehir.edu.tr https://orcid.org/0000-0002-5020-9801

${ }^{2}$ Eskişehir Technical University, Faculty of Sports Science, Eskişehir-Turkey, e-posta:huseyincevik@eskisehir.edu.tr https://orcid.org/0000-0002-3555-7322

${ }^{3}$ Eskişehir Technical University, Faculty of Sports Science, Eskişehir-Turkey, e-posta:aomercanoglu@eskisehir.edu.tr https://orcid.org/0000-0002-7812-9870 


\section{INTRODUCTION}

In order to create recreational activities and events in leisure industry, there are tasks such as consultancy, management, project production, activity leadership, sales, distribution and booking of the services, delivering the infrastructure for the organization and production of the materials to be used. The number of privatized sports facilities is on the increase in the gradually industrializing world and they have turned into seek-profit enterprises. When recreation industry is reviewed, it is observed that recreational facilities, which provide sports as leisure and recreational services, lead the most dominant sectors. However, many sectors exist within this industry aside from recreational sports facilities. Individuals, who want to value their time with recreational activities aside from the time for working and vital needs, spend their time by participating in activities and events in six different areas. These are; sports, health, arts, social and cultural activities and education. There are even some recreational activities that meet needs of a few different areas. For instance, primary aim of an individual who register in a sports center is to exercise. Additionally, the individual socializes by participating in activities organized by the enterprise for members such as trekking, picnic etc., and values his time to improve himself by joining training activities provided within the enterprise. It is a significant point that the people to provide recreation services, which are related to a wide range of areas, have the qualities that can meet these services. Ardelean (2013) also emphasizes that there is a need for well-trained recreation specialists who can plan and program individually or for groups. It is of significance to determine main qualities of recreation experts that the sector needs today, where there is a large variety of recreational activities in private sector. Within this regard, the aim of the research is to determine the main qualities that recreation experts, who will be employed in Turkish recreation industry, should have.

\section{Recreation and Employment}

The last 10 years period represents radical economic, social and political changes and transformation for Turkey. While this period of change has developed a more economy and market based model, it also has laid the groundwork for decrease of public's weight in the system, diminishing of agriculture's relative significance and developing of a structure integrated with global competition. It is inevitable for this transformation to affect labor markets, employment structure and sectoral distributions in the country. There is an ongoing pain of an evolution period directed to a labor suitable for expectations of enterprises, which are trying to keep with global competition with a labor market which has limited productivity, is closed to competition and does not have flexibility. A more flexible, more competitive and highly qualified labor profile is also expectation of the new model in this process (SETA Analysis, 2010). This expectation certainly applies for recreation experts who are required to have a more flexible, more competitive and highly qualified labor profile needed by Turkish recreation industry. The question to be answered at this point is; are qualified recreation experts being employed basing on the expectation set by the economic model in Turkey?

Recreation experts in Turkey are being employed in three public institutions; local authorities, Ministry of National Education (MNE) and Ministry of Youth and Sports (MYS). However, when recreation expert employment results in public institutions are reviewed, it is not possible to access any statistical data regarding employment of recreation experts in local authorities. Recreation experts should graduate from a four-year undergraduate program and then receive a one-year pedagogic formation training in order to be employed in MNE. Afterwards, they are employed basing on their results in Public Personnel Selection Examination (MEB, 2011). When recreation experts' employment data in MYS are analyzed, it is seen that 50 recreation experts were employed only in 2013. In 2016, there have been employments under titles of trainers, sports dietician, sports training expert, sports physiotherapist, sports massager and sports psychologist but recreation experts were not assigned (GSB, 2016). Yet, when student quota for recreation departments in higher education institutions according to 
2020 OSYM guidance booklet is observed, it is seen that 2513 students in total were accepted in 21 universities in daytime and evening education. However, employment rate is quite lower than this number. Eventually, most of the recreation experts have to be employed in private sector.

It is seen that the concept of recreation is being understood more day by day thanks to the organizations held in Turkey. However, a critical point to pay attention is that this understanding is unilateral. In other words, the necessity of experts to provide recreation services is felt more by private sector. When the content of higher education programs that involve recreation experts is reviewed, it is seen that these programs do not meet the needs of the private sector. It is a debatable issue to graduate recreation experts from sports or tourism based higher education programs while there is such a large variety of activity within recreation industry. Therefore, it significant to reveal the qualities recreation experts should have depending on the perspective of enterprises in private sector.

\section{Research Model}

This research based on qualitative research perspective and was designed in inductive manner in its natural environment. It was tried to determine main qualities of recreation experts, which are needed by the private sector in recreation industry, and emotions, opinions and perspectives of participants of the research.

\section{Participants}

Population of the research consists of managers of enterprises providing service in Turkish recreation industry. Participants to the study group of the research were senior managers ( 9 person) of the enterprises that have a high rate of employment and serve in sport recreation, tourism recreation, public and local government recreation, nongovernmental organization, shopping recreation, park recreation, commercial recreation, adventure recreation and outdoor recreation. Detailed information about demographic variables related to managers is given in Table 1.

\section{METHOD}

Table 1. Demographic Information about Managers

\begin{tabular}{|c|c|c|c|c|c|c|c|}
\hline Participants & Gender & Age & $\begin{array}{l}\text { Work } \\
\text { Experience }\end{array}$ & $\begin{array}{l}\text { Educational } \\
\text { Background }\end{array}$ & $\begin{array}{l}\text { Place of } \\
\text { residence }\end{array}$ & Organization & $\begin{array}{l}\text { Recreation } \\
\text { Field }\end{array}$ \\
\hline P1 & $\mathrm{M}$ & 45 & 25 & Master degree & İstanbul & Vialand & $\begin{array}{l}\text { Park } \\
\text { Recreation }\end{array}$ \\
\hline $\mathrm{P} 2$ & $\mathrm{M}$ & 55 & 30 & $\begin{array}{l}\text { Undergraduate } \\
\text { degree }\end{array}$ & Antalya & Crystal Hotels & $\begin{array}{l}\text { Tourism } \\
\text { Recreation }\end{array}$ \\
\hline P3 & $\mathrm{M}$ & 38 & 16 & $\begin{array}{l}\text { Undergraduate } \\
\text { degree }\end{array}$ & Eskişehir & $\begin{array}{l}\text { Özdilek } \\
\text { Qualitas SPA }\end{array}$ & $\begin{array}{l}\text { Sport } \\
\text { Recreation }\end{array}$ \\
\hline $\mathrm{P} 4$ & $\mathrm{~F}$ & 42 & 14 & $\begin{array}{l}\text { Undergraduate } \\
\text { Degree }\end{array}$ & İstanbul & Kidzania & $\begin{array}{l}\text { Shopping } \\
\text { Recreation }\end{array}$ \\
\hline P5 & $\mathrm{M}$ & 43 & 15 & $\begin{array}{l}\text { Undergraduate } \\
\text { degree }\end{array}$ & Ankara & $\begin{array}{l}\text { Eğriova } \\
\text { Nature Park }\end{array}$ & $\begin{array}{l}\text { Outdoor } \\
\text { Recreation }\end{array}$ \\
\hline P6 & $\mathrm{F}$ & 52 & 21 & $\begin{array}{l}\text { Undergraduate } \\
\text { degree }\end{array}$ & Eskişehir & $\begin{array}{l}\text { Eskişehir } \\
\text { Tepebaşı } \\
\text { Municipality }\end{array}$ & $\begin{array}{l}\text { Public and } \\
\text { Local } \\
\text { Government } \\
\text { Recreation }\end{array}$ \\
\hline P7 & $\mathrm{M}$ & 55 & 28 & Master Degree & İstanbul & $\begin{array}{l}\text { Creative } \\
\text { Activities, } \\
\text { Planning and } \\
\text { Implementatio } \\
\text { n Association }\end{array}$ & $\begin{array}{l}\text { Non- } \\
\text { Governmental } \\
\text { Organization }\end{array}$ \\
\hline P8 & $\mathrm{M}$ & 57 & 30 & Master Degree & İstanbul & $\begin{array}{l}\text { Turkey } \\
\text { Entertainment } \\
\text { Industry } \\
\text { Association }\end{array}$ & $\begin{array}{l}\text { Non- } \\
\text { Governmental } \\
\text { Organization }\end{array}$ \\
\hline P9 & $\mathrm{M}$ & 35 & 15 & $\begin{array}{l}\text { Undergraduate } \\
\text { degree }\end{array}$ & Antalya & Uzer Group & $\begin{array}{l}\text { Commercial } \\
\text { Recreation }\end{array}$ \\
\hline
\end{tabular}


Table 1 shows that most of participants are male and six of them are graduates of undergraduate programs and three of master's degree programs. Their ages range between 35 and 57 and they have work experiences in the sector ranging between 15 years and 30 years. They all reside in big cities of Turkey and the companies provide service in park, tourism, sport, outdoor, commerce, public and local government recreation, and nongovernmental organization.

\section{Data Collection}

In the scope of the study, the researchers aimed to obtain in-depth information. For this reason, the data were collected by using a qualitative data collection method. In-depth semi-structured interview technique was benefited to collect data within the research. The following steps were taken while preparing the semi-structured interview form to be used as the data collection tool.

- Based on the literature review, semistructured interview questions were prepared and shared with two nonparticipant academician and two experts in the field in order to ensure reliability.

- The final form was prepared according to feedback received from experts. The following questions were asked to the participants.

1. What is the recreational application you most need in your business?

2. What are the existing recreational employment opportunities in Turkey?

3. What do you think should be the characteristics of the recreation expert?

4. What should be done in Turkey for the employment of recreation specialist?

5. What are the courses you consider indispensable in recreation curriculum?

The researchers informed the participants about the study and the procedures before the interviews. They requested the participants filled out consent forms. After the consent form was filled out, they asked permission for voice recording before the interview begun. Two different audio recorders were used during the interviews. The participants were also told that no one else except the researcher will listen to these recordings or read the transcripts.

The participants were invited for purpose of informing students about the job opportunities in recreation industry within the project supported by Anatolian University Scientific Research Projects Commission (project number 11408S369). The meetings continued for ten weeks between March 2015 and May 2015. The researchers interviewed a participant during their visit. The interviews was conducted in meeting room of Faculty of Sport Sciences. The duration of the interviews ranged between 45 minutes and 90 minutes. The researchers gave codes to participants instead of their real names. The voice record was transformed to the transcripts after the interviews were finished. Later, the transcripts were sent to the participants the so that they can check them for accuracy. No negative feedback was received from the participants.

\section{Data Analysis}

Content analysis was used in order to analyze research data. Data analysis stages, recommended by Jones et al. (2013), were followed in this parallel. These stages are; Data management: (data organization, alignment and storage) transcription: (deciphering of interviews and field notes) acknowledgement stage: (review of collected data) reducing: (creating codes, categories and themes).

The peer questioning, negative situation analysis, explaining researcher prejudices, member control, intensive description and external inspection were paid attantion for quality of the research. Moreover, consensus of coders was paid regard to for reliability (Creswell, 2007). Two researchers took part in the coding of the data. Inter-coder reliability was calculated using the formula suggested by Miles \& Huberman (1994) for inter-coder compatibility. According to the formula, the reliability coefficient is obtained by dividing the number of agreed items by the total number of agreed and unreconciled items and multiplying the obtained result by 100 . 
The value for reliability coefficient between the coder is expected above 0.70 .

\section{Validity and Reliability}

In order to ensure validity and to increase the reliability of the study, certain strategies were used persuasiveness, transferability, consistency and objectivity (Yıldırım \& Şimşek, 2016). To ensure persuasiveness, the transcripts were sent to the participants and their approvals were taken for accuracy. The analyses were done regularly and the findings obtained were compared, interpreted and conceptualized. The method of the study was explained clearly in detail and the findings were supported through direct quotations from the transcripts for transferability. Consistency was achieved by taking an expert's opinions during the coding of the data. Inter-coder reliability was calculated for consistency according to Miles and Huberman's (1994) formula. The threshold is 0.70 . The researcher calculated as 0.89 for this study.

\section{RESULTS}

\section{The Results of Content Analysis}

Findings acquired as a result of the research were identified as code and theme. As a result of the research, the qualities that recreation experts should have were determined as; competency and knowledge, event management knowledge and experience, management and organization knowledge and experience, business management experience and knowledge and leadership. Codes and themes obtained as a result of the analysis are presented in Table 2

Table 2. Analysis Results Related to Qualitative Interviews of the Managers: Main theme, Subthemes and Codes

\begin{tabular}{|c|c|c|}
\hline Theme & Sub-themes & Codes \\
\hline \multirow{5}{*}{ Qualifications } & $\begin{array}{l}\text { Management and Organization } \\
\text { Knowledge and Experience }\end{array}$ & $\begin{array}{l}\text { Planning } \\
\text { Organization } \\
\text { Coordination } \\
\text { Motivation } \\
\text { Control }\end{array}$ \\
\hline & $\begin{array}{l}\text { Business Management Knowledge } \\
\text { and Experience }\end{array}$ & $\begin{array}{l}\text { Production } \\
\text { Financial } \\
\text { Marketing } \\
\text { Human Resources } \\
\text { AR-GE (Project Management) } \\
\text { Public Relations } \\
\end{array}$ \\
\hline & $\begin{array}{l}\text { Event Management Knowledge and } \\
\text { Experience }\end{array}$ & $\begin{array}{l}\text { Design } \\
\text { Planning } \\
\text { Coordination } \\
\text { Evaluation }\end{array}$ \\
\hline & Leadership & $\begin{array}{l}\text { Belonging } \\
\text { Creativity } \\
\text { Being Up-to-date } \\
\text { Responsibility } \\
\text { Communication Skill } \\
\text { Cultural Level } \\
\text { Analytical Solution Skills } \\
\text { Teamwork } \\
\text { Entrepreneurship }\end{array}$ \\
\hline & Competency and Adequacy & $\begin{array}{l}\text { Field Knowledge (Sport, Tourism, Workplace, } \\
\text { Therapeutic, Outdoor, Municipal, Campus } \\
\text { recreation etc.) } \\
\text { Foreign Language } \\
\text { First Aid and Health Information } \\
\text { Job Security Knowledge } \\
\text { Internship } \\
\text { Moving Skills }\end{array}$ \\
\hline
\end{tabular}




\section{DISCUSSION}

The idea that activities, which seek or do not seek profit, can be held in a recreative way within an organization has started to be acknowledged in Turkish business world as well. Therefore, the supports given to huge organizations in private sector have increased and recreation has started to be used as an instrument to reach commercial goals. In parallel, public sector holds organizations in order to transmit target-based activities to the society in a recreative way. Public sector might choose to conduct joint works with private sectors in order to acquire financial support. Thanks to commissions working in cooperation and the areas created in this line, it is possible to provide more comprehensive recreative organizations to the society (Şimşek, 2013). By courtesy of the support provided by public and private sector to the organizations, society's desire to benefit from recreational activities increases each passing day. This can be exemplified by national and international festivals held by public sector or municipalities in many cities (Great Ankara Festival, Kemaliye International Nature and Sports Festival, Samsun International Folk Dances Festival, International Dead Sea Air Games Festival etc.) and recreational parks (Ankapark, Vialand, Istanbul Aquarium,

Tekirova Ecopark, Jurassicland, Parkantep, Kocaeli Ottoman-Themed Culture and Art Park, İzmir Natural Life Park, Landora Theme Park, Temaworld etc.) (Şimşek, 2013).

It is observed that the concept of recreation is associated with sports and tourism in higher education institutions providing education to recreation experts in Turkey. A main reason for this situation is recreation departments were opened in sports sciences faculties/physical education and sports colleges or tourism faculties. However, when the body of literature is reviewed, it is seen that recreation holds such a vast area that it would not fit in two giant industries such as sports and tourism. Recreation's multidisciplinary nature obligates relations with many industries for individuals, willing to spend their potential leisure with recreational activities, do not spend their time only exercising or participating in recreational activities. This specific time might be associated with arts, culture, health and education occasionally.

When curriculums of recreation departments are reviewed, it is seen that courses base on sports, tourism, public and activity leadership. On the other hand, recreation experts should function as both implementer and manager. As in every branch of business, experts in recreation area should acquire these two main characteristics. However, programs do not deliver adequate opportunities for this. Paying particular attention on the management aspect is significant for recreation experts to get to be employed as white-collar in the future and increase their economic gain.

As a result of interviews with managers of enterprises, which have high rate of employment in Turkish recreation industry, it was tried to establish the qualities that recreation experts should have. A recreation expert should possess certain "qualities and competencies" specific to his/her area of employment. For instance, "K2" emphasized the significance of qualities and competencies as such.

"The students should be well-equipped. It is rather easy to be a vice manager or manager with this equipment. You need time for experience and experience will bring you a lot. What I understand is that you are expressing the importance of internship. They should start doing internship as of the first year but I mean real internships, not pretendinternships

When general differences of the sectors in recreation industry are dealt, there are different qualities and competencies for each sector that will facilitate being employed. Qualities and competencies of recreation experts should be determined basing on the sector they will be employed. In parallel with this view, Schneider et al. (2006) stated that in order to be employed as a student employee, it is one of the primary requirements for candidates to have certificates related to the field they will apply. In addition, it is stated that the experience background of the relevant position is one of the factors that is of great importance in the employment process. It 
must not be forgotten that recreation experts should be implementer (activity leadership) rather than manager in order to obtain required qualities and competencies. Similar to this view, Hurd et al. (2014) stated that students in the field of recreation need to carry their classroom knowledge to real experiences. Real experiences increase students' self-confidence so they feel prepared and competent when starting their first professional assignment.

Variety of products in recreation industry brings along diversity of activities and events. This diversity requires recreation experts to possess certain qualities concerning activity management. Enterprise managers in the sector touch upon the significance of this quality. Another quality that private sector seeks in recreation experts is "activity management knowledge and experience". "K3" emphasized the significance of activity management knowledge and experience as such.

"They should be strong in activity management part, which is our field, enough that they know how a system is run, how a project is conducted, how a project is turned into organization and implementation. For this reason, it is necessary to teach all the details of life".

In today's Turkey, the number of recreative organizations held by public and private sector has increased and became varied day by day. This varying can be exemplified employment areas such as recreational touristic trip (historical places, museums, theme parks etc.), adventurous recreation (nature sports, extreme sports), sports, concert and festival trip (homeland/abroad), recreational activities with social and training content (implementations in municipalities and schools), private sports centers (plates, yoga, zumba etc. course programs), therapeutic recreation (implementations with elders, differently abled, prisoner, soldier etc.) recreative shopping (organizations basing on consumer and advertising in Shopping Malls), entertainment and animation (package program shows, meeting the need for recreation experts) recreative industry organizations (group dynamic and productivity increasing implementations for employees of industrial enterprises) and campus recreation (activities aimed at sociocultural, sportive and artistic needs of students and employees) (Şimşek, 2013). A great many and different recreation activities are being held in these areas. Therefore, it is inevitable for a recreation expert to possess activity management knowledge and skills.

In the literature, it is possible to say that the opinion of the authors that experts in different fields of recreation should have the knowledge and skills of event management is accepted. For example, according to Barcelona et al. (2016), activity management knowledge and skills are one of the qualifications that sport recreation experts needed to have. Hazar (2014), Hacioğlu, Gökdeniz, and Dinç (2009) similarly emphasize that recreation experts working in the animation department of accommodation establishment should have this feature. According to Şimşek (2018), the recreation experts need to have this competency regardless of recreation fields. Shortly, the different author's opinions on this topic contribute to the literature supporting the results that emerged in this study.

Recreation experts are assigned in two positions in the enterprises they are employed. First, they are managers of the job and second, they are implementers of the job; in other words, activity leadership. Therefore, there is a group and system to direct even if they are managers or activity leaders. Command and control of this group and system lie in "management and organization knowledge and skills". "K4"s statement on recreation experts' management knowledge and skills are as such.

"The world has changed. There is a multidisciplinary environment in the project and we need specialized people and teams coming from that multidiscipline environment. Our skill is to manage all these people coming from different places and different disciplines."

Management is a compulsory function for organizations to attain their goals in an efficient and effective way. Looking from the 
perspective of recreation management, recreation experts should know how to plan, organize, motivate, coordinate and inspect all activities pertaining to recreation (Argan et al., 2013). The conducted researches show supporting results that recreation experts should have management knowledge and skills. Tsitskari et al. (2017)'s study examined the characteristics that play a role in the employment of sports recreation experts, and the issue of organization management emerged as a feature that facilitates employment. Tripolitsioti et al. (2007)' study examined the competencies required to manage health, fitness clubs, and indoor facilities in municipalities, the management knowledge and skill are defined as a necessary feature according to the result of the analysis. Management techniques were identified as the most important factor in the study in which Barcelona and Ross (2004) examined the competencies required for sports recreation managers in campus, local governments, and military recreation areas. In this respect, the results of these studies are consistent with other studies and contribute to the literature.

There are many enterprises producing different goods and services in recreation industry. There is especially a great number of enterprises producing service. These enterprises employ recreation experts in positions such as manager, assistant manager and activity leader etc. As a result of the analysis of research data, it was found that "business management knowledge and skills" is another quality that recreation experts should possess. "K1" emphasized the following regarding business management knowledge and skills of recreation experts.

"They should know that they are halfmanagers and make plans for everything they will present or do. It is fundamental that an expert has planning skills. They should know what to do. Details, preparations are important. An expert should be able to prepare a process."

Enterprises in recreation industry deliver their recreational services to consumers through recreation experts. It is known that recreation experts, who are employed in enterprises, ought to possess certain qualities regarding services. A primary element that ensures optimum quality level of service is competent "leadership qualities" of recreation expert providing the service (Barcelona, Wells \& Arthur-Banning, (2016). Regarding the leadership qualities, "K2" stated the following.

"There is this thing... No matter what the sector is, whether they are implementers or managers, there is always the issue of leadership. Leadership always comes first whether they are managers or just managing the activity."

While leadership does not mean management, it cannot be considered separately from management. There might be a leader of an unorganized group. However, there are managers in organized groups which involve special roles. Leadership is a significant element of management. The skill to lead is a factor that produces effective management. A good leader should be associated with both humans and results. It is stated that high level of leadership skills are necessary in producing policies, delivering work and controlling of personnel in recreation management (Torkildsen, 2005).

In the literature, it can be said that there is a common view that the recreation expert should have leadership characteristics. In the research conducted by Hammersley and Tynon (1998), the entry-level job competencies specified for resort and commercial recreation professionals were collected under 9 categories. When these 9 categories are ranked in order of priority, it is seen that the first 5 characteristics are communication skills, leadership, guest services, programming, and supervision. In Hurd's (2005) study, the competencies of park and recreation experts have been gathered under 5 general categories: communications, community relations, interpersonal skills, leadership and management, and professional practice. The general qualification categories are divided into 15 subcategories, and a total of 53 specific qualifications are defined under these subcategories. The most important of these specific qualifications are the ability to communicate clearly with customers, the 
ability to listen to staff and customers, the ability to deal with the public, the ability to communicate clearly with staff, knowing how to act professionally, and the ability to manage multiple tasks. Hurd and McLean (2004) defined one of the qualifications required for managerial positions in public parks and recreation agencies as a leadership characteristic. According to the results of this research, leader managers should be openminded and open to new ideas, know leadership principles, be exemplary, motivate employees, notice employees' success and reward them, see the organization and employees as a team, take risks. They also should be creative and innovative and ease employees to do their jobs. In short, it is understood from the researches that recreation experts should have leadership qualities for both the implementer and manager positions. The result of this study is consistent with the literature in this sense.

When other studies are examined about the competencies needed by the recreation expert, it is noteworthy that the findings that emerged in this study were similar to these researches. In the study conducted by Schneider et al. (2006), the most important characteristics considered in new recruitment in the field of campus recreation were examined in three groups: professional positions, graduate assistantships, and student employees. Although there are differences between these three groups, the prominent characteristics are excellent language/speaking and writing skills, prior experience related to the position applied for, neat overall appearance, and certificates. The high ranking of language/speaking and writing skills indicates that communication skills are an important attribute sought in potential job candidates. In another study by Chase and Masberg (2008) examining competencies in the field of park and recreation, the required skills/competencies were listed by collecting data from managers working in the field. When 15 skills found in this study are ranked according to their importance level, it has been found that the first 5 skills are communications, personality/interpersonal, knowledge of profession, adaptability, and responsibility. In the study conducted by
D'Eloia and Fulthorp (2016) on employment in municipal recreation agencies, the qualifications of park and recreation graduates were investigated. As a result of the research, three different themes have emerged about how university students can better prepare for employment in municipal recreation agencies. These are experience, interview skills, and job awareness.

When the studies in the literature are evaluated, it is seen that the qualities that a recreation expert should have partially differ according to the fields of employment. However, when evaluated in general, it can be stated that characteristics such as experience, communication, leadership, management, and competency in profession come to the fore (Hammersley \& Tynon, 1998; Hurd, 2005; Schneider et al., 2006; Chase \& Masberg, 2008; Hurd et al., 2014; D'Eloia \& Fulthorp, 2016). In this study, unlike the studies in the literature, it was revealed that communication skill is a quality associated with leadership and has an important position especially in this respect.

As a result, the main qualities that a recreation expert should possess from the perspective of Turkish recreation industry are listed as competencies and qualities, event management knowledge and skills, management and organization knowledge and skills, business management knowledge and skills and leadership. These qualities were established as the basic characteristics that enterprises operating in today's private sector expect from a recreation expert.

\section{RECOMMENDATIONS}

It is yet to be understood that existing recreation-wise employment opportunities in public and private sector are in fact an action taken under the roof of recreation. Therefore, recreation department graduates have difficulty in recreational employment. Additionally, absence of studies aiming at recreation expert employment within government policies leave graduates of this department to future concerns. In an attempt to eliminate these concerns and problems, it is required to communicate with relevant authorities of the government, create study 
groups and determine necessary legal arrangements and conduct required works so as to put these plans into practice. In addition, below recommendations should be taken into consideration.

- Increasing knowledge and experience of instructors who are experts of the area,

- Determining and accrediting occupational adequacy,

- Developing a common curriculum and internship opportunities,

- Creating a cooperation between university and industry and

- Making necessary legal arrangements regarding employment.

\section{Limitations and Future Research}

Events and trends which have occurred in the course of time might cause changes in the qualities sought in a recreation expert. Therefore, it is recommended to support similar researches and update basic qualities that a recreation expert should have before private sector. In addition, the similarities and differences can be examined by comparing the characteristics of the recreation expert needed in different sectors in future research. Especially for certain positions, possible differences can be a guide for the development of the qualifications of the recreation expert in the transition to professional life.

\section{Acknowledgments}

We would like to thank the all managers who participated in our study.

\section{Disclosure statement}

No potential conflict of interest was reported by the authors.

\section{REFERENCES}

Argan, M., Yüncü, D., Coşkun, İ.O., Sevil, T., Özel, ÇH., Yüncü, RH., Şimşek, KY. (2013). Rekreasyon Yönetimi Eskişehir: Anadolu Üniversitesi Web-ofset Tesisleri.

Barcelona, B., Ross, CM. (2004). An Analysis of the Perceived Competencies of Recreational Sport Administrators.
Journal of Park \& Recreation Administration, 22(4), 25-42.

Barcelona, RJ., Wells, MS., Arthur-Banning, S. (2016). Recreational Sport: Program Design, Delivery, and Management. Champaign, IL: Human Kinetics.

Chase, DM., Masberg, BA. (2008). Partnering for skill development: Park and recreation agencies and university programs. Managing Leisure, 13(2), 74-91.

Creswell, JW. (2007). Qualitative inquiry and research design: Choosing among five approaches. 2nd ed. Thousand Oaks: Sage Publications

D'Eloia, MH., Fulthorp, K. (2016). Preparing for the profession: Practitioner perceptions of college student preparedness for entrylevel, full-time employment in municipal recreation agencies. Schole: A Journal of Leisure Studies and Recreation Education, 31(1), 15-28.

Hacıoğlu, N., Gökdeniz, A., Dinç, Y. (2009). Boş zaman \& rekreasyon yönetimi: Örnek animasyon uygulamalar Ankara: Detay Yayıncilik.

Hammersley, CH., Tynon, JF. (1998). Job competencies of entry-level resort and commercial recreation professionals. Journal of Applied Recreation Research, 23(3), 225-241.

Hazar, A. (2014). Rekreasyon ve Animasyon Ankara: Detay Yayıncilık.

Hurd, AR. (2005). Competency Development for Entry Level Public Parks and Recreation Professionals. Journal of Park \& Recreation Administration, 23(3), 45-62.

Hurd, AR., Elkins, DJ, Beggs, BA. (2014). Using competencies to assess entry-level knowledge of students graduating from parks and recreation academic programs. Schole: A Journal of Leisure Studies and Recreation Education, 29(1), 51-59.

Hurd, AR., McLean, DD. (2004). An analysis of the perceived competencies of CEOs in public park and recreation agencies. Managing Leisure, 9(2), 96-110.

Jones, I., Brown L., Holloway I. (2013). Qualitative research in sport and physical activity. London: Sage Publications.

Miles, MB., Huberman, AM. (1994). Qualitative Data Analysis: An Expanded Sourcebook. Thousand Oaks: Sage Publications.

Milli Eğitim Bakanlığı (MEB), (2011). Personel Genel Müdürlüğ̈̈ Ögrretmenlik İçin Başvuru ve Atama Kllavuzu (Haziran 2011). Available from: http://personel.meb.gov.tr/kilavuzlar/\%C3 
Şimşek, K.Y., Çevik, H. \& Mercanoğlu, A.O. (2021). Main Qualifications Required for Employment of Recreation Experts: The Perspective of Sector Representatives. International Journal of Recreation and Sport Science, 5 (1); 31-41.

$\% 96 \%$ C4\%9Fretmenlik\%20\%C4\%B0\%C $3 \%$ A7in $\% 20 \mathrm{Ba} \% \mathrm{C} 5 \% 9$ Fvuru\%20ve $\% 20$ Atama\%20K\%C4\%B1lavuzu\%20(2011\% 20Haziran).pdf

OSYM, (2020). 2020 Yükseköğretim Programlart ve Kontenjan Kllavuzu. Available from: https://www.osym.gov.tr/TR,19431/2020yuksekogretim-kurumlari-sinavi-yksyuksekogretim-programlari-vekontenjanlari-kilavuzu.html.

Republic of Turkey Ministry of Youth and Sports, (2018). T.C. Gençlik ve spor bakanlı̆̆ spor genel müdürlüğü sözleşmeli spor uzmanı ve sözleşmeli antrenör alımı duyurusu Available from: https://gsb.gov.tr/Duyuru/137084/tcgenclik-ve-spor-bakanligi-spor-genelmudurlugu-sozlesmeli-spor-uzmani-vesozlesmeli-antrenor-alimi-duyurusu.aspx

SETA Analysis. (2010). Türkiye'de istihdam durumu: Genel eğilimler [Employment situation in Turkey: General trends]. [cited 2016 Sep 20]. Available from: http://arsiv.setav.org/Ups/dosya/35324.pdf

Schneider, RC., Stier, Jr WF, Kampf, S, Haines, SG, Wilding, G. (2006). Characteristics, attributes, and competencies sought in new hires by campus recreation directors. Recreational Sports Journal, 30(2), 142-153.

Şimşek, KY. (2013). The commercial recreation and service quality in malls. Pamukkale Journal of Sport Sciences, 4(3), 53-75.

Şimşek, KY. (2018). Ticari Rekreasyon Ankara: Detay Yayıncilik.

Torkildsen G. (2005). Leisure and recreation management. Abingdon: Psychology Press

Tripolitsioti, A, Moudakis, K, Konstantinakos, P, Theodorikakos, P. (2007). The management competencies of the directors of youth centres and indoor facilities in the municipalities. Biology of Exercise, 3, 4757.

Tsitskari, E, Goudas, M, Tsalouchou, E, Michalopoulou, M. (2017). Employers' Expectations of the Employability Skills Needed in the Sport and Recreation Environment. Journal of Hospitality, Leisure, Sport \& Tourism Education, 20(1), 1-9.

Yıldırım, A., Şimşek, H. (2016). Sosyal Bilimlerde Nitel Araştırma Yöntemleri. Ankara: Seçkin Yayıncılık. 


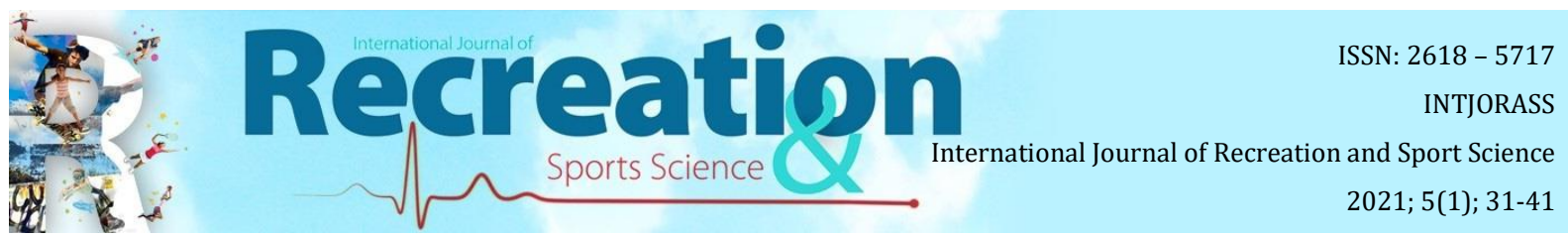

Research Article - https://doi.org/10.46463/ijrss.917073

\title{
Rekreasyon Uzmanlarının İstihdamı İçin Gerekli Temel Nitelikler: Sektör Temsilcilerinin Bakış Açısı
}

\author{
Kerem Yıldırım ŞİMŞEK ～Hüseyin ÇEVIKK Anıl Onur MERCANOĞLU
}

$\ddot{O} z$

Kamu kurumlarında rekreasyon uzmanları çok sınırlı düzeyde istihdam edilmektedir. Kamu kurumlarında istihdam kısıtlamaları rekreasyon bölümü mezunlarını özel sektöre yönlendirmektedir. Bu durum rekreasyon bölümü mezunlarının niteliklerinin özel sektörün rekreasyon uzmanında aradığı özelliklerle örtüşmesini gerektirmektedir. Bu gereklilik doğrultusunda araştırmanın amacı, Türkiye'de rekreasyon sektöründe istihdam edilecek rekreasyon bölümü mezunlarında aranan temel özellikleri belirlemektir. Araştırmada ölçüt örnekleme yöntemi ile belirlenen katılımcılarla yarı yapılandırılmış görüşmeler yapılmıştır. Araştırma grubu; spor rekreasyonu, turizm rekreasyonu, alışveriş rekreasyonu, park rekreasyonu, macera rekreasyonu ve açı hava rekreasyonu hizmetleri veren ve istihdam oranı yüksek işletmelerin üst düzey yöneticilerinden oluşmaktadır. Görüşmeler sonucunda elde edilen veriler üzerinde nitel veri analizi yöntemlerinden içerik analizi yapılmıştır. Araştırma bulguları incelendiğinde rekreasyon mezunlarında aranan özelliklerin beş tema altında toplandığı görülmektedir. Ortaya çıkan özellikler, eğitim programlarının yeniden düzenlenmesinde ve istihdam süreçlerinde bir rehber olarak kullanılabilir. Bu çalışmada rekreasyon bölümü mezunlarının endüstride ihtiyaç duyulan temel özellikleri ve rekreasyon bölümü eğitim programlarının geliştirilmesi konusunda öneriler sunulmuştur.

Anahtar Kelimeler: İstihdam, rekreasyon uzmanı, rekreasyon endüstrisi

\section{GíRiş}

Boş zaman endüstrisinde rekreasyonel aktivite ve etkinliklerin oluşturulması için ortaya konan hizmetlerin danışmanlığı, yönetimi, proje üretimi, aktivite liderliği, satışı, dağıtımı, rezervasyonların oluşturulması, organizasyon ile ilgili alt yapının sağlanması ve kullanılan malzemelerin üretimi gibi faaliyetler yer almaktadır. Endüstrileşen dünyada özelleştirilmiş rekreasyon tesislerinin sayısı giderek artış göstermekte ve kar amacı güden tesisler haline gelmektedir. Rekreasyon endüstrisi incelendiğinde en baskın sektörlerin başında sporun boş zaman ve rekreasyon hizmetleri olarak sunulduğu rekreasyonel tesisler gelmektedir. Ancak, rekreasyonel spor tesisleri haricinde birçok sektör bu endüstrinin içerisinde varlığını sürdürmektedir. Çalışma ve zorunlu ihtiyaçların giderildiği zamanın dışında kalan zaman dilimini rekreasyonel faaliyetlerle değerlendirmek isteyen bireyler zamanlarını alt1 farklı alanda yer alan aktivitelere ve etkinliklere katılarak tüketmektedir. Bunlar; spor, sağlık, sanat, sosyal, kültürel ve eğitim olarak sıralanabilir. Bireyler ihtiyaçlarına göre bu alanların birini, bir kaçını ya da hepsini tercih edebilmektedir. Hatta öylesine rekreasyonel faaliyetler vardır ki birkaç alanda ortaya çıkan ihtiyaçları karşılamaktadır. Örneğin, spor merkezine üye olan bireyin öncelikli amacı spor yapmaktır. Bunun yanı sıra birey, işletme tarafindan üyeler için organize edilen trekking, piknik vb. aktivitelere katılarak sosyalleşmekte, dahası işletme içerisinde sunulan eğitim faaliyetlerine katılarak kendini geliştirmek için zamanını değerlendirmektedir. Bu kadar çeşitli alanla ilişkisi olan rekreasyon hizmetini sağlayacak olan bireylerin de bu hizmetleri karşılayabilecek özelliklere sahip olması rekreasyon uzmanının istihdamı için elzem bir konudur. Ardelean, (2013) de bireysel ya da gruba yönelik planlama ve programlama yapabilen iyi eğitim almış rekreasyon uzmanlarına ihtiyaç olduğunu vurgulamaktadır. Özel sektör içerisinde rekreasyonel faaliyetlerin bu kadar 
çeşitlendiği bir dönemde sektörün ihtiyaç duyduğu rekreasyon uzmanının temel özelliklerinin belirlenmesi önem arz etmektedir. Bu bağlamda araştırmanın amacı, Türk rekreasyon endüstrisi içerisinde istihdam edilecek rekreasyon uzmanlarının sahip olması gereken temel özellikleri belirlemektir.

\section{Rekreasyon ve İstihdam}

Türkiye için son 10 y1llık dönem, ekonomik, sosyal ve siyasal alanda köklü değişim ve dönüşümlerin yaşandığı bir dönemi temsil etmektedir. Bu değişim süreci bir yandan daha rekabetçi ekonomi ve piyasa odaklı bir model geliştirirken, öte yandan kamunun sistemdeki ağırlığının azaldığı, tarımın göreceli öneminin kaybolduğu ve küresel rekabetle bütünleşmiş bir yapının gelişmesine zemin hazırlamıştır. $\mathrm{Bu}$ dönüşümün ülkedeki işgücü piyasalarını, istihdam yapısını ve sektörel dağılımları etkilemesi kaçınılmaz bir sonuçtur. Üretkenliği sinırlı, rekabete kapalı ve esnekliği olmayan bir işgücü piyasasından küresel rekabete ayak uydurmaya çalışan işletmelerin beklentilerine uygun bir işgücüne dönük evrimleşme sürecinin sancıları sürmektedir. $\mathrm{Bu}$ süreçte daha esnek, daha rekabetçi ve yükssek vasıflı bir işgücü profili, yeni ekonomik modelin de beklentisi olarak ortaya çıkmaktadır (SETA Analiz, 2010). Bu beklenti elbette ki Türk rekreasyon endüstrisinin ihtiyaç duyduğu daha esnek, daha rekabetçi ve yüksek vasıflı bir işgücü profiline sahip olması gereken rekreasyon uzmanları için de geçerlidir. Bu noktada cevap aranan soru ise şudur; Türkiye'deki ekonomik modelin ortaya koyduğu beklentiye göre nitelikli rekreasyon uzmanı istihdam edilmekte midir?

Türkiye'de rekreasyon uzmanları yerel yönetimler, Milli Eğitim Bakanlığı (MEB) ve Gençlik ve Spor Bakanlığı (GSB) olmak üzere üç kamu kurumunda istihdam edilmektedir. Ancak, kamu kurumlarındaki rekreasyon uzmanı istihdam sonuçları incelendiğinde, yerel yönetimlerdeki rekreasyon uzmanlarının atamalarına yönelik herhangi bir istatistiki veriye ulaşılamamaktadır. Rekreasyon uzmanlarının MEB'de istihdam edilebilmeleri için dört yıllık lisans programının ardından bir yıl süreli pedagojik formasyon eğitimi almaları gerekmektedir. Sonrasında Kamu Personeli Seçme Sınavı (KPSS) sonucuna göre istihdam edilmektedirler (MEB, 2011). Rekreasyon uzmanlarının GSB'deki istihdam verileri incelendiğinde ise sadece 2013 yılında 50 kişilik rekreasyon uzmanı atamasının yapıldığ 1 görülmektedir. 2016 yılında kuruma antrenör, spor beslenmecisi, spor eğitim uzman1, spor fizyoterapisti, spor masörü ve spor psikoloğu unvanları adı altında istihdam yapılmış ancak, rekreasyon uzmanı atamalarına yer verilmemiştir (GSB, 2016). Oysaki, 2020 ÖSYM k1lavuzuna göre yükseköğretim kurumlarındaki rekreasyon bölümleri için öğrenci kontenjanları incelendiğinde 21 üniversitede birinci ve ikinci öğretim olmak üzere toplam 2513 öğrenciye öğrenim hakk1 verildiğgi görülmektedir. Ancak, istihdam rakamları bu kontenjan oranının oldukça altındadır. Sonuç olarak rekreasyon uzmanlarının büyük çoğunluğu özel sektörde istihdam edilmek zorundadır.

Türkiye'de düzenlenen organizasyonlar sayesinde rekreasyon olgusunun gün geçtikçe anlaşıldığı görülmektedir. Ancak, dikkat edilmesi gereken çok önemli bir nokta bu anlaşılmanın tek taraflı olmasıdır. Yani rekreasyon hizmetini icra edecek olan uzman ihtiyacının özel sektör tarafından daha fazla hissediliyor olmasıdır. Oysaki rekreasyon uzmanlarının tabi olduğu yüksek öğretim programlarının içeriği dikkatlice incelenecek olursa, özel sektörün bu ihtiyacını giderecek özellikleri sergilemediği anlaşılmaktadır. Rekreasyon endüstrisi içerisindeki faaliyetler bu kadar geniş ve çeşitli iken rekreasyon uzmanlarını spor ya da turizm temelli yüksek öğretim programlarından mezun etmek tartışılması gereken bir konudur. Dolayısıyla, özel sektörde yer alan işletmelerin bakış açısına göre rekreasyon uzmanında olması gereken özelliklerin ortaya koyulması önem arz etmektedir.

\section{YÖNTEM}

\section{Araştırma Modeli}

$\mathrm{Bu}$ araştırma nitel araştırma bakış açısını temel alarak doğal ortamında tümevarımcı bir şekilde tasarlanmıştır. Araştırmaya 
katılanların, duygu, düşünce ve bakış açılariyla rekreasyon endüstrisinde yer alan özel sektörün ihtiyaç duyduğu rekreasyon uzmanının temel özellikleri belirlenmeye çalışılmıştır.

\section{Katılımcilar}

Araştırmanın evrenini, Türkiye rekreasyon endüstrisinde hizmet veren işletmelerin Tablo 1. Yöneticilerin demografik bilgileri yöneticileri oluşturmaktadır. Araştırmanın çalışma grubunu spor, turizm, kamu ve yerel yönetim rekreasyonu, sivil toplum kuruluşları, alışveriş, park rekreasyonu, ticari rekreasyon, macera ve açık alan rekreasyonu alanlarında hizmet veren ve istihdam oranı yüksek olan işletmelerin üst düzey yöneticileri ( 9 kişi) oluşturmuştur. Yöneticilerle ilgili detaylı demografik bilgiler Tablo 1'de verilmiştir.

\begin{tabular}{ccccccc}
\hline Katılımcı & Cinsiyet & Yaş & $\begin{array}{c}\text { İş } \\
\text { Deneyimi }\end{array}$ & Eğitim Durumu & $\begin{array}{c}\text { Yaşadı̆̆ı } \\
\text { Yer }\end{array}$ & Rekreasyon Alanı \\
\hline K1 & M & 45 & 25 & Yüksek Lisans & İstanbul & Park Rekreasyonu \\
\hline K2 & M & 55 & 30 & Lisans & Antalya & Turizm Rekreasyonu \\
\hline K3 & M & 38 & 16 & Lisans & Eskişehir & Spor Rekreasyonu \\
\hline K4 & K & 42 & 14 & Lisans & İstanbul & Alışveriş Rekreasyonu \\
\hline K5 & M & 43 & 15 & Lisans & Ankara & Açık Alan Rekreasyonu \\
\hline K6 & K & 52 & 21 & Lisans & Eskişehir & $\begin{array}{c}\text { Kamu ve Yerel Yönetim } \\
\text { Rekreasyonu }\end{array}$ \\
\hline K7 & M & 55 & 28 & Yüksek Lisans & İstanbul & Sivil Toplum Kuruluşu \\
\hline K8 & M & 57 & 30 & Yüksek Lisans & İstanbul & Sivil Toplum Kuruluşu \\
\hline K9 & M & 35 & 15 & Lisans & Antalya & Ticari Rekreasyon \\
\hline
\end{tabular}

Tablo 1'e göre katılımcıların çoğu erkektir, altısı lisans mezunu ve üçü yüksek lisans eğitim düzeyine sahiptir. Yaşları otuz beş ve elli yedi arasında değişmektedir ve sektörde on beş ile otuz yıl arasında değişen iş deneyimine sahiptirler. Hepsi Türkiye'nin büyük şehirlerinde yaşamaktadır ve çalıştıkları kurumlar park, turizm, spor, açık alan rekreasyonu, ticari rekreasyon, kamu ve yerel yönetim rekreasyonu ve sivil toplum kuruluşu olarak hizmet sağlamaktadır.

\section{Veri Toplama Tekniği}

Çalışma kapsamında, araştırmacılar derinlemesine bilgi elde etmeyi amaçlamışlardır. Bunun için, araştırma verileri nitel veri toplama yöntemi kullanılarak elde edilmiştir. Araştırmada veri toplamak için derinlemesine yarı yapılandırılmış görüşme tekniğinden yararlanılmıştır. Veri toplama aracı olarak kullanılan yarı yapılandırılmış görüşme formu hazırlanırken aşağıdaki adımlar dikkate alınmıştır.

- Güvenirliği sağlamak için literatür incelemesi temelinde yarı yapılandırılmış görüşme soruları hazırlanmış ve araştırmacılar dışında iki akademisyen ve alan uzmanıyla paylaşılmıştır.

- Uzmanlardan gelen önerilere göre forma son şekli verilmiştir. Katılımcılara aşağıdaki sorular yöneltilmiştir.

1. İşletmenizde en çok ihtiyaç duyduğunuz rekreasyon uygulaması nedir?

2. Türkiye'deki mevcut rekreasyon istihdam olanakları nelerdir?

3. Sizce rekreasyon uzmanının özellikleri neler olmalıdır?

4. Türkiye'de rekreasyon uzmanı istihdamı için neler yapılmalıdır?

5. Rekreasyon müfredatında gerekli gördüğünüz dersler nelerdir? 
Araştırmacılar, görüşmelerden önce katılımcıları araştırma ve süreç hakkında bilgilendirmişlerdir. Katılımcılardan gönüllü onam formu doldurmaları rica edilmiştir. Gönüllü onam formu doldurulduktan sonra, görüşmeler başlamadan önce ses kaydı için izin istenmiştir. Görüşmeler sırasında iki farklı ses kayıt cihazı kullanılmıştır. Katılımcılara araştırmacıların dışında bu kayıtları kimsenin dinlemeyeceği ve deşifre edilen metinleri okumayacağı söylenmiștir.

Katılımcılar rekreasyon endüstrisindeki iş firsatlarıyla ilgili öğrencileri bilgilendirmek amaciyla Anadolu Üniversitesi Bilimsel Araştırmalar Komisyonu tarafından desteklenen (Proje No: 11408S369) proje kapsamında davet edilmiştir. Toplantılar 2015 Mart ve Mayıs ayları arasinda on hafta sürmüştür. Araştırmacılar katılımcılarla ziyaretleri sırasında görüşmüşlerdir. Görüşmeler Spor Bilimleri Fakültesinin toplantı salonunda gerçekleştirilmiştir. Görüşme süreleri kırk beş ve doksan dakika arasında değişmektedir. Araştırmacılar katılımcıların gerçek adları yerine kod kullanmıştır. Ses kayıtları görüşmeler bittikten sonra transkripsiyonlara dönüştürülmüş̧tür. Daha sonra, transkripsiyonlar, doğruluğunu kontrol etmeleri amaciyla katılımcılara gönderilmiştir.

\section{Verilerin Analizi}

Araştırma verilerinin analizi için içerik analizinden yararlanılmıştır. $\mathrm{Bu}$ doğrultuda Jones ve ark. (2013) tarafindan önerilen veri analizi aşamaları takip edilmiştir. $\mathrm{Bu}$ aşamalar; veri yönetimi (verinin düzenlenmesi, siralanmas1 ve depolanmasi), transkripsiyon (görüşmeler ve saha notlarının deşifre edilmesi), tanıma (toplanan veri gözden geçirilmesi) ve indirgeme (kodların, kategorilerin ve temaların oluşturulması)'dir. Araştırmanın kalitesi için uzun süreli katılım ve gözlem, çeşitleme, akran sorgulaması, negatif durum analizi, araştırmacı önyargılarının açıklanması, üye kontrolü, yoğun betimleme ve diş denetim aşamaları önerilmektedir. Ayrıca, güvenirlik için kodlayıcılar arasında görüş birliği dikkate alınmıştır (Creswell, 2007). Veri kodlamasında iki araştırmacı görev almıştır.
Kodlayıcılar arası güvenilirlik, kodlayıcılar arası uyumluluk için Miles \& Huberman (1994) tarafindan önerilen formül kullanılarak hesaplanmıştır. Formüle göre güvenirlik katsayısı, üzerinde anlaşılan madde sayısının, üzerinde anlaşılan ve uyuşmayan toplam madde sayısına bölünmesi ve elde edilen sonucun 100 ile çarpılmasıyla elde edilmektedir. Kodlayıcılar arası güvenirlik katsayısı değerinin 0.70 üzerinde olması beklenmektedir.

\section{Geçerlik ve Güvenirlik}

Araştırmanın geçerliliğini sağlamak ve güvenirliğini artırmak için inandırıcılık, aktarılabilirlik, tutarlılık ve nesnellik stratejileri kullanılmıştır (Yıldırım \& Şimşek, 2016). İnandırıcılığ1 sağlamak için transkriptler katılımcilara gönderilmiş ve doğruluk için katılımcıların onayları alınmıştır. Analizler düzenli olarak yapılmış ve elde edilen bulgular karşılaştırılmış, yorumlanmış ve kavramsallaştırılmıştır. Çalışmanın yöntemi ayrıntılı olarak açıklanmış ve aktarılabilirlik açısından transkriptlerden doğrudan alıntılar yapılarak bulgular desteklenmiştir. Verilerin kodlanması sırasında uzman görüşü alınarak tutarlılık sağlanmıştır. Tutarlılık için kodlayıcılar arası güvenirlik Miles ve Humerman'ın (1994) formülüne göre hesaplanmıştır. Güvenirlik için eşik değer 0.70'dir. Araştırmacılar bu çalışma için güvenirlik değerini 0.89 olarak hesaplamıştır.

\section{BULGULAR}

\section{İçerik Analizi Sonuçları}

Araştırma sonucunda elde edilen bulgular kod, kategori ve tema olarak tanımlanmıştır. Analiz sonucunda rekreasyon uzmanında olması gereken temel özellikler; yeterlilik ve donanım, etkinlik yönetimi bilgisi ve deneyimi, yönetim ve organizasyon bilgisi ve deneyimi, işletme yönetimi bilgisi ve deneyimi ve liderlik olarak saptanmıştır. Analiz sonucunda ortaya çıkan kodlar ve temalar Tablo 2'de gösterilmiştir. 
Tablo 2. Yöneticilerle Yapılan Nitel Görüşmelere İlişkin Analiz Sonuçları: Tema, Alt Temalar ve Kodlar.

\begin{tabular}{|c|c|c|}
\hline Tema & Alt Temalar & Kodlar \\
\hline \multirow{35}{*}{ 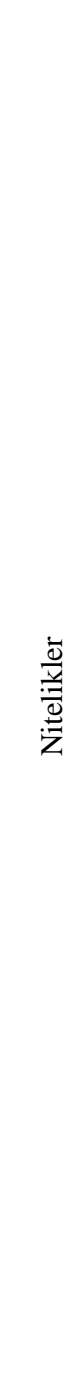 } & Yönetim ve & Planlama \\
\hline & Organizasyon & Organizasyon \\
\hline & Bilgisi, & Koordinasyon \\
\hline & Becerisi, & Motivasyon \\
\hline & Deneyimi ve & Kontrol \\
\hline & Tecrübesi & \\
\hline & & Üretim \\
\hline & Işletme & Finans \\
\hline & Yönetimi & Pazarlama \\
\hline & Bilgisi, & İnsan Kaynakları \\
\hline & Becerisi, & AR-GE (Proje Yönetimi) \\
\hline & Deneyimi ve & Halkla İlişkiler \\
\hline & Tecrübesi & \\
\hline & Etkinlik & Tasarım \\
\hline & Yönetimi & Planlama \\
\hline & Bilgisi, & Koordinasyon \\
\hline & Becerisi, & Değerlendirme \\
\hline & Deneyimi ve & \\
\hline & Tecrübesi & \\
\hline & & Aidiyet \\
\hline & & Yaraticilik \\
\hline & & Güncellenme \\
\hline & & Sorumluluk \\
\hline & Liderlik & İletişim Becerisi \\
\hline & & Kültürel Düzey \\
\hline & & Analitik Çözüm Becerisi \\
\hline & & Takım Çalışması \\
\hline & & Girişimcilik \\
\hline & & $\begin{array}{l}\text { Alan Bilgisi (spor, turizm, iş } \\
\text { yeri, terapatik, açık alan, } \\
\text { yerel yönetim ve kampüs } \\
\text { rekreasyonu vb.) }\end{array}$ \\
\hline & Donanım ve & Yabanc1 Dil \\
\hline & Yeterlilik & İlk Yardım ve Sağlık Bilgisi \\
\hline & & İş Güvenliği Bilgisi \\
\hline & & Oyun Bilgisi \\
\hline & & Staj \\
\hline & & Hareket Becerisi \\
\hline
\end{tabular}

\section{TARTIŞMA VE SONUÇ}

Kar amacı güden ya da gütmeyen aktivite ve etkinliklerin rekreasyonel olarak bir organizasyon kapsamında gerçekleştirilebileceği düşüncesi Türk iş dünyası içerisinde kabul görmeye başlamıştır. $\mathrm{Bu}$ durum özel sektörde büyük organizasyonlara verilen desteği arttırmış ve ticari amaçlara ulaşabilmek için rekreasyon bir araç olarak kullanılmaya başlanmıştır. Buna paralel olarak, amaçlı etkinliklerin rekreatif bir şekilde topluma ulaştırılması için kamuda da organizasyonlar düzenlemektedir. $\mathrm{Bu}$ noktada kamu, finansal destek sağlayabilmek için özel sektörle ortak çalışmalar içerisine girebilmektedir. $\mathrm{Bu}$ sayede ortak çalışma komisyonları ve alanları oluşturularak topluma daha kapsamlı rekreatif organizasyonlar sunulmaktadır (Şimşek, 2013). Türkiye'de kamu ve özel sektör tarafindan organizasyonlara verilen destek sayesinde toplum içerisinde rekreasyonel etkinliklerin yararlarından faydalanma isteği ise gün geçtikçe artmaktadır. Buna, birçok şehirde yerel yönetimler veya özel sektör tarafindan düzenlenen ulusal ve uluslararası festivaller (Büyük Ankara Festivali, Kemaliye Uluslar Arası Doğa ve Spor Şenlikleri, Samsun Uluslar Arası Halk Dansları Festivali, Uluslar Arası Ölüdeniz Hava Oyunları Festivali vb.) ve rekreasyonel parklar (Ankapark, Vialand, İstanbul Akvaryum, Tekirova Ekopark, Jurassicland, Parkantep, Kocaeli Osmanlı Temalı Kültür Sanat Park1, İzmir Doğal Yaşam Parkı, Landora Temalı Park1, Temaworld vb.) örnek olarak gösterilebilir (Şimşek, 2013).

Türkiye'de rekreasyon uzmanlarının eğitim aldığı yüksek öğretim kurumlarında rekreasyon olgusunun spor ve turizm ile bağdaştırıldığı gözlemlenmektedir. $\mathrm{Bu}$ durumun temel sebeplerinden birisi rekreasyon bölümlerinin spor bilimleri fakülteleri/beden eğitimi ve spor yüksekokullarında ya da turizm fakültelerinde açılmış olmasıdır. Ancak alan yazını incelendiğinde, rekreasyonun spor ve turizm gibi iki dev endüstriye sığdırılamayacak kadar geniş bir alana sahip olduğu açıkça görülmektedir. Rekreasyonun çok alanlı (multidisipliner) oluşu birçok endüstri ile ilişki kurmasını zorunlu kılmaktadır. Çünkü, potansiyel boş zamanlarını rekreasyonel aktivitelerle değerlendirmek isteyen bireyler zamanlarını sadece spor yaparak ya da turizme dayalı rekreasyonel aktiviteler yaparak değerlendirmemektedir. $\mathrm{Bu}$ değerlendirme faaliyeti bazen sanatla, kültürle, bazen sağlıkla ve eğitimle ilişkili olabilmektedir.

Rekreasyon bölümlerinin ders programları incelendiğinde, derslerin spora, turizme, kamuya ve aktivite liderliğine dayandırıldığı görülmektedir. Oysaki rekreasyon uzmanının hem uygulayıcı hem de yönetici olması gerekmektedir. Her iş kolunda olduğu gibi 
rekreasyon alanında da uzmanların bu iki temel özelliği edinmesi gerekir. Ancak, programlar buna yeterli olanağı sağlamamaktadır. Özellikle işin yönetim kısmını dikkate almak, rekreasyon uzmanlarının ilerleyen yıllarda beyaz yaka olarak istihdam edilme firsatlarını yakalayabilmesi ve ekonomik kazancını artırabilmesi için elzemdir.

Araştırma kapsamında Türkiye rekreasyon endüstrisinde istihdam oranı yüksek olan işletme yöneticileri ile yapılan görüşmeler sonucunda rekreasyon uzmanında olması gereken nitelikler belirlenmeye çalışılmıştır. Rekreasyon uzmanının istihdam edildiği alana özgü bazı "donanımlara ve yeterliliklere" sahip olmas1 gerekmektedir. Örneğin, "K2" donanım ve yeterliliğin önemini şu şekilde vurgulamıştır.

"K2. Çocukların alan ile ilgili donanım çok iyi sahip olması lazım, bu donanımı aldıktan sonra gidip bir yerde yönetici yardımcisl ya da yönetici olmaları hakikatten kolay. Tecrübe zamanla gelen bir şey. Tecrübe tabi çok şey kazandirlyor. Illk yıldan itibaren sıkı stajlar yapılmalı ama gerçek stajlardan bahsediyorum. Çorba değil yani. Mış gibi değil"

Rekreasyon endüstrisindeki sektörlerin genel farklılıkları dikkate alındığında her bir sektörde istihdam edilmeyi kolaylaştırabilecek donanım ve yeterlilikler farklılık göstermektedir. Rekreasyon uzmanının donanım ve yeterlilikleri istihdam edileceği sektöre yönelik belirlenmelidir. $\mathrm{Bu}$ görüşe paralel olarak Schneider ve ark., (2006) tarafından yapılan çalışmada, öğrenci işçi olarak istihdam olabilmek için, adayların başvuruda bulunacakları alanla ilgili sertifikalara sahip olmasının öncelikli gerekliliklerden biri olduğu belirtilmiştir. Ayrıca ilgili pozisyona ait deneyim geçmişinin istihdam edilme sürecinde büyük önem verilen unsurlardan biri olduğu ifade edilmektedir. Rekreasyon uzmanlarının gerekli donanım ve yeterliliği elde edebilmesi için de işin yönetmekten ziyade işin uygulayıcıs1 (aktivite liderliği) olması gerektiği unutulmamalıdır. Hurd ve ark., (2014) bu görüşe paralel olarak, rekreasyon alanındaki öğrencilerin sınıflarda edindiği mesleki bilgileri gerçek deneyimlere taşımaya ihtiyac1 olduğunu belirtmektedir. Böylece kendini hazırlıklı ve yeterli hissedeceği için ilk mesleki görevine başladığında gereken özgüvene sahip olabilecektir.

Rekreasyon endüstrisinin içerisinde ürün yelpazesinin çok geniş olması beraberinde aktivite ve etkinlik çeşitliliğini getirmektedir. $\mathrm{Bu}$ çeşitlilik, rekreasyon uzmanının etkinlik yönetimi ile ilgili özelliklere sahip olmasını gerektirmektedir. Sektörde yer alan işletme yöneticileri bu özelliğin öneminden bahsetmektedir. Özel sektörün rekreasyon uzmanında aradığı bir diğer özellik "etkinlik yönetimi bilgisi ve becerisi"dir. Bununla ilgili "K3" etkinlik yönetimi bilgisi ve becerisi" önemini şu şekilde vurgulamıştır.

"K3. Etkinlik yönetimi dediğimiz alanda çok güçlü olmalılar $k i$, bir sistemi nasıl yönetiyorlar, nasıl projelendiriyorlar, nasıl organize ediyorlar, nasıl uygulamaya dönüştürüyorlar çok doğru bilmeleri lazım. Onun için de o hayatın bütün detaylarını iyi ögretmek lazım"

Günümüz Türkiye'sinde özel sektör tarafindan düzenlenen rekreatif organizasyonların sayısı gün geçtikçe artmakta ve çeşitlenmektedir. $\mathrm{Bu}$ çeşitlenmeye, rekreasyonel turizm seyahati (tarihi alanlar, müzeler, temalı parklar vb. geziler), macera rekreasyonu (doğa sporları, ekstrem sporlar), spor, konser ve festival seyahati (yurt içi/dışı), sosyal ve eğitim içerikli rekreasyonel etkinlikler (belediyeler ve okullarda yapılan uygulamalar), özel spor merkezleri (pilates, yoga, zumba vb. kurs programları), terapatik rekreasyon (yaşl1, engelli, mahkum, asker vb. özel gruplar yapılan uygulamalar), rekreatif alışveriş̧ (AVM'lerde reklam ve tüketici odaklı yapılan rekreatif organizasyonlar), eğlence ve animasyon (gösteriye yönelik paket programlar, rekreasyon uzmanı ihtiyacinın karşılanması), iş yeri rekreasyonu (sanayi işletmelerinde çalışanlarına grup dinamiği, iş verimi artırma vb. uygulamalar) ve kampüs rekreasyonu (öğrenci ve çalışanların sosyokültürel, sportif ve sanatsal ihtiyaçlarına yönelik etkinlikler) gibi istihdam alanları 
örnek olarak verilebilir (Şimşek, 2013). Bu alanlarda farklı türlerde bir çok rekreasyon etkinliği düzenlenmektedir. Dolayısıyla, rekreasyon uzmanında etkinlik yönetimi bilgisi ve becerisinin olması kaçınılmazdır.

Literatürde yazarlar tarafindan rekreasyonun farklı alanlarında uzmanların ekinlik yönetimi bilgi ve becerisine sahip olması gerektiği görüşünün kabul gördüğünü söylemek mümkündür. Örneğin Barcelona, Wells \& Arthur-Banning, (2016)'e göre ekinlik yönetimi bilgi ve becerisi, spor rekreasyonu uzmanın sahip olması gereken yeterlilikler arasında yer almaktadır. Hazar (2014) ile Hacıoğlu, Gökdeniz ve Dinç (2009) de benzer şekilde turizm rekreasyonu kapsamında konaklama işletmelerinde animasyon departmanında çalışan rekreasyon uzmanlarının bu özelliği sahip olması gerektiğini vurgulamaktadır. Şimşek (2018)'e göre ise, alan fark etmeksizin rekreasyon uzmanlarının bu yeterliliğe sahip olması gerekmektedir. Kısacası, farklı yazarların bu konudaki görüşleri, araştırmada ortaya çıkan sonucu destekleyerek, literatüre katk1 sağlamaktadır.

Rekreasyon uzmanları istihdam edildikleri işletmelerde iki pozisyonda yer almaktadır. Birincisi işin yöneticisi, ikincisi ise işin uygulayıcısı yani aktivite liderliğidir. Dolayısıyla, yönetici de olsa aktivite lideri de olsa yönetmesi gereken bir grup ve sitem bulunmaktadır. Bu sistemin ve grubun sevk ve idaresi ise "yönetim ve organizasyon bilgisi ve becerisi" inden geçmektedir. Rekreasyon uzmanının yönetim bilgisi ve becerisi konusunda "K4" ün ifadesi aşağıdaki gibidir.

K4. "Dünya değişti. Projenin yapımında multidisiplin bir ortam ve o multidisiplinden gelmiş olan birçok konuda ihtisaslaşmış insanlar ve ekipler gerekiyor. Bizim yetimizse bütün bu değişik yerlerden gelen değişik disiplinlerden gelen insanlarin hepsini birden yönetmek".

Yönetim, örgütlerin amaçlarına etkin ve verimli ulaşabilmeleri bakımından zorunlu bir işlevdir. Rekreasyon yönetimi açısından bakıldığında boş zamanın değerlendirilmesi ile ilgili olan tüm faaliyetlerin planlanması, organizasyonu, motivasyonu, koordinasyonu ve denetimi rekreasyon uzmanları tarafindan bilinmesi gerekmektedir (Argan ve ark., 2013). Yapılan araştırmalar bu özelliğin rekreasyon uzmanlarında olması gerektiğin destekler sonuçlar ortaya koymaktadır. Tsitskari vd. (2017)'nin spor rekreasyonu uzmanlarının istihdamında rol oynayan özellikleri incelediği çalışmada, organizasyon yönetimi konusu istihdamı kolaylaştıran bir özellik olarak ortaya çıkmıştır. Tripolitsioti vd. (2007)'nin belediyelerde sağlık, fitness kulüpleri ve kapalı alan tesislerini yönetmede gerekli olan yeterlilikleri incelediği çalışmada da yönetim bilgi ve becerisi gerekli bir özellik olarak analizler sonucunda tanımlanan bir faktördür. Barcelona ve Ross (2004)'un kampüs, yerel yönetimler ve askeri rekreasyon alanlarında spor rekreasyonu yöneticileri için gerekli yeterlilikleri incelediği çalışmada, yönetim teknikleri en önemli faktör olarak tanımlanmıştır. $\mathrm{Bu}$ açıdan bu araştırmaların sonuçları diğer çalışmalar ile tutarlık ortaya koyarak, literatüre katkı sağlamaktadır.

Rekreasyon endüstrisinde farklı mal ve hizmet üreten birçok işletme bulunmaktadır. Özellikle hizmet üreten işletme sayısının fazla olduğu söylenebilir. $\mathrm{Bu}$ işletmelerde rekreasyon uzmanları yönetici, yönetici asistan1, aktivite liderliği vb. pozisyonlarda istihdam edilmektedirler. Araştırma verilerinin analizi sonucu rekreasyon uzmanında olması gereken diğer bir özellik "işletme yönetimi bilgisi ve becerisi" olarak ortaya çıkmıştır. Rekreasyon uzmanının işletme bilgisi ve becerisi konusunda "K1" şunu vurgulamıştır

K1. "Yönetici ya da yönetici yarısı olduğunun farkina varmalarl ve işletmede sunacakları hizmetlerin ya da yapacaklar her şeyin yönetilmesini gerektiğini anlamalı. Uzmanda planlama olmast şart. Neler yapması gerektiğini bilmesi şart, detaylar şart, süreçleri hazırlamaları şart uzmanın, bir şeyin sürecini hazırlayabilmesi lazım uzmanin"

Rekreasyon endüstrisindeki işletmeler, ürettikleri rekreasyonel hizmetleri tüketiciye rekreasyon uzmanları vasitasıyla 
ulaştırmaktadır. İşletmelerde istihdam edilen rekreasyon uzmanlarının hizmete yönelik belli başı nitelikleri taşıması gerektiği bilinmektedir. Verilen hizmet kalitesinin üst düzeyde olmasını sağlayan başlıca unsurlardan biri ise hizmeti veren rekreasyon uzmanının yetkin "liderlik özellikleridir" (Barcelona, Wells \& Arthur-Banning, (2016). Liderlik özelliği ile ilgili "K2" şunu ifade etmiştir.

K2. "Şöyle bir şey var, hangi sektörde çalışırsa çalışsınlar uygulayıcı boyutunda da çalışsalar, yönetici boyutunda da çalışsalar, eğlence boyutunda da çalışsalar hep liderlik yapıyorlar. Yönetici de olsalar ya da etkinlikte liderlikte yapsalar hep bir liderlik var. Liderlik liderlik liderlik"

Liderlik, yönetim anlamına gelmemesine rağmen yönetimden ayrı düşünülemez. Organize olmamış bir grupta lider olabilir. Ancak, özel rollerin olduğu düzenli yapılarda yönetici bulunmaktadır. Liderlik, yönetimin önemli bir parçasıdır. Yol gösterme yeteneği etkili yöneticiliği ortaya koyan faktörlerden birisidir. İyi bir lider hem insan ile hem de sonuçlarla ilişkilendirilmektedir. Rekreasyon yönetiminde politika üretmede, icraatlar ortaya koymada ve personelin sevk ve idaresinde üst düzey liderlik özelliğine ihtiyaç duyulduğu ifade edilmektedir (Torkildsen, 2005).

Literatürde, rekreasyon uzmanının liderlik özelliğine sahip olması gerektiği konusunda ortak bir görüşün olduğunu söylenebilir. Hammersley ve Tynon (1998) tarafindan yapılan araştırmada tatil köyü ve ticari rekreasyon uzmanları için belirtilen giriş düzeyi iş yetkinlikleri 9 kategori altında toplanmıştır. Bu 9 kategori öncelik sırası göz önüne alınarak sıralandığında, ilk 5 özelliğin iletişim becerileri, konuk hizmetleri, programlama, denetleme/kontrol ve liderlik olduğu görülmektedir. Hurd (2005)'un araştırmasında, park ve rekreasyon uzmanlarının yeterlilikleri; iletişim, toplum ilişkileri, kişilerarası beceriler, liderlik ve yönetim, mesleki uygulama olmak üzere 5 genel kategori altında toplanmıştır. Genel yeterlilik kategorileri 15 alt kategoriye ayrilmakta ve alt kategorilerin altında

toplamda $53 \quad$ belirli yeterlilik

tanımlanmaktadır. $\mathrm{Bu}$ belirli özel yeterliliklerden en önemlileri; müşterilerle açıkça iletişim kurma yeteneği, personeli ve müşterileri dinleme yeteneği, halkla başa çıkma yeteneği, personel ile açık bir şekilde iletişim kurma yeteneği, profesyonelce nasıl hareket edileceğini bilmek ve birden fazla görevi yönetme yeteneği olarak gösterilmektedir. Hurd ve McLean (2004) ise kamu park ve rekreasyon ajanslarında yönetici pozisyonu için gerekli yeterliliklerden birini liderlik özelliği olarak tanımlamıştır. $\mathrm{Bu}$ araştırma sonucuna göre liderlik özelliği altında yöneticiler; açık fikirli ve yeni fikirlere açık olmalı, liderlik prensiplerini bilmeli, örnek olmalı, çalışanları motive etmeli, çalışanların başarılarını görmeli ve ödüllendirmeli, örgütü ve çalışanları bir takım olarak görmeli, risk almalı, yaratıcı ve yenilikçi olmalı, çalışanların işlerini yapmalarını kolaylaştırmalıdır. Kısacası, literatürdeki araştırmalardan rekreasyon uzmanının hem uygulayıcı hem de yönetici pozisyonu için liderlik özelliğine sahip olmaları gerektiği anlaşılmaktadır. $\mathrm{Bu}$ araştırmada ortaya çıkan sonuç bu anlamda literatürle tutarlıl1k göstermektedir.

Rekreasyon uzmanın ihtiyaç duyduğu yeterlilikler konusunda diğer araştırmalar incelendiğinde, bu araştırmada ortaya çıkan ve onlarla ilişkili bulgulara ulaşıldığı dikkati çekmektedir. Schneider ve ark., (2006) tarafından yapılan çalışmada, kampüs rekreasyonu alanındaki işe alımlarda dikkate alınan en önemli özellikler; profesyonel çalışanlar, lisansüstü asistanlık ve öğrenci çalışanlar olmak üzere üç grupta incelenmiştir. Bu üç grup arasında farklılıklar olmakla birlikte öne çıkan özellikler; dil/konuşma ve yazma becerisi, başvurulan pozisyonla ilgili deneyim geçmişi, düzgün/temiz genel görünüm, ve sahip olunan sertifikalar olarak belirtilmiş̧ir. Dil/konuşma ve yazma becerilerinin üst siralarda yer alması, iletişim becerilerinin potansiyel iş adaylarında aranan önemli bir özellik olduğunu göstermektedir. Chase ve Masberg (2008) tarafindan park ve rekreasyon alanında yeterliliklerin incelendiği başka bir çalışmada, alanda çalışan yöneticilerden veri toplanarak gerekli olan beceri/yeterlilikler sıralanmıştır. 
Söz konusu olan çalışmada bulunan 15 beceri önem derecesine göre siralandığında ilk 5 sirada yer alan becerilerin iletişim, kişilik/kişilerarası, meslek bilgisi, uyum yeteneği ve sorumluluk olduğu bulunmuştur. D'Eloia ve Fulthorp (2016) tarafindan belediye rekreasyon ajanslarındaki istihdama yönelik yapılan çalışmada park ve rekreasyon mezunlarının yeterliliklerinin ne olması gerektiği araştırılmıştır. Araştırma sonucunda, üniversite öğrencilerinin belediye rekreasyon ortamlarında istihdama nasil daha iyi hazırlanabileceklerine ilişkin üç farklı tema ortaya çıkmıştır. Bunlar; deneyim (rekreasyonla ilgili), mülakat becerileri (öz sunum, sözlü ve yazılı iletişim becerileri) ve iş bilinci (ajans, topluluk ve konum özellikleri ve beklentiler) olarak belirtilmiştir.

Literatürde yer alan çalışmalar değerlendirildiğinde istihdamın söz konusu olduğu alanlara göre rekreasyon uzmanın sahip olması gerektiği özelliklerin kısmen farklılaştığ1 görülmektedir. Ancak genel olarak değerlendirildiğinde, deneyim, iletişim, liderlik, yönetim, mesleki donanım gibi özelliklerin ön plana çıktığı ifade edilebilir (Hammersley ve Tynon, 1998; Hurd, 2005; Schneider ve ark., 2006; Chase ve Masberg, 2008; Hurd ve ark., 2014; D'Eloia ve Fulthorp, 2016). Bu çalışmada literatürdeki araştırmalardan farklı olarak, iletişim becerisinin daha çok liderlikle ilişkilendirilen bir nitelik olduğu ve özellikle bu açıdan önemli bir yere sahip olduğu ortaya konulmuştur.

Sonuç olarak, Türk rekreasyon endüstrisi bakış açsına göre rekreasyon uzmanında olması gereken temel özellikler donanımlar ve yeterlilikler, etkinlik yönetimi bilgisi ve becerisi, yönetim ve organizasyon bilgisi ve becerisi, işletme yönetimi bilgisi ve becerisi ve liderlik olarak siralanmaktadır. $\mathrm{Bu}$ özellikler günümüz şartlarında özel sektörde faaliyet gösteren işletmelerin rekreasyon uzmanında olmasını beklediği özellikler olarak belirlenmiştir.

\section{ÖNERILER}

Türkiye'de kamu ve özel sektörde rekreatif anlamda var olan iş olanaklarının rekreasyon çatısı altında yapılan bir eylem olduğu henüz tam olarak anlaşılamamıştır. Dolayısıyla, rekreasyon bölümü mezunları istihdamda sorun yaşamaktadır. Ayrıca, devlet politikaları çerçevesinde rekreasyon uzmanı istihdamına yönelik çalışmaların olmayışı, mezun olan öğrencileri gelecek kaygısıyla baş başa bırakmaktadır. Bu kaygı ve problemin ortadan kaldırılabilmesi için devletin ilgili kurumları ile iletişime geçilmesi, çalışma gruplarının oluşturulması, ihtiyaç duyulan yasal düzenlemelerin belirlenmesi ve hayata geçirilmesi için çalışmaların yapılması önerilmektedir. Buna ilaveten aşağıdaki önerilerde göz önünde bulundurulmalıdır;

- Alan uzmanı öğretim elemanlarının bilgi, deneyim ve tecrübelerinin artırılması,

- Mesleki yeterliliğin belirlenmesi ve akredite edilmesi,

- Ortak ders programinin ve staj olanaklarının geliştirilmesi,

- Üniversite sanayi işbirliklerinin oluşturulması ve

- İstihdam konusunda yasal düzenlemelerin yapılması gerekmektedir.

\section{SINIRLILIKLAR VE GELECEK ARAŞTIRMALAR}

Zaman içerisinde gelişen olaylar ve eğilimler rekreasyon uzmanında aranan özelliklerin değişmesine sebep olabilir. Dolayısıyla özel sektör için rekreasyon uzmanında olması gereken temel özellikler benzer araştırmalarla desteklenerek güncellenmesi önerilmektedir. Buna ek olarak ileride yapilacak araştırmalarda, farklı sektörlerde ihtiyaç duyulan rekreasyon uzmanının özellikleri karşılaştırılarak benzerlikler ve farklılıklar incelenebilir. Olası farklılıklar, profesyonel hayata geçiş sürecinde rekreasyon uzmanının sahip olduğu niteliklerin, istihdamın hedeflendiği alana özgü geliştirilmesi konusunda yol gösterici bir nitelik taşıyabilir.

\section{KAYNAKLAR}

Argan, M., Yüncü, D., Coşkun, İ.O., Sevil, T., Özel, ÇH., Yüncü, RH., Şimşek, KY. (2013). Rekreasyon Yönetimi Eskişehir: Anadolu Üniversitesi Web-ofset Tesisleri.

Barcelona, B., Ross, CM. (2004). An Analysis of the Perceived Competencies of Recreational Sport Administrators. Journal of Park \& Recreation Administration, 22(4), 25-42. 
Barcelona, RJ., Wells, MS., Arthur-Banning, S. (2016). Recreational Sport: Program Design, Delivery, and Management. Champaign, IL: Human Kinetics.

Chase, DM., Masberg, BA. (2008). Partnering for skill development: Park and recreation agencies and university programs. Managing Leisure, 13(2), 74-91.

Creswell, JW. (2007). Qualitative inquiry and research design: Choosing among five approaches. 2nd ed. Thousand Oaks: Sage Publications

D'Eloia, MH., Fulthorp, K. (2016). Preparing for the profession: Practitioner perceptions of college student preparedness for entry-level, full-time employment in municipal recreation agencies. Schole: A Journal of Leisure Studies and Recreation Education, 31(1), 1528.

Hacioğlu, N., Gökdeniz, A., Dinç, Y. (2009). Boş zaman \& rekreasyon yönetimi: Örnek animasyon uygulamalart Ankara: Detay Yayıncilik.

Hammersley, CH., Tynon, JF. (1998). Job competencies of entry-level resort and commercial recreation professionals. Journal of Applied Recreation Research, 23(3), 225241.

Hazar, A. (2014). Rekreasyon ve Animasyon Ankara: Detay Yayıncilık.

Hurd, AR. (2005). Competency Development for Entry Level Public Parks and Recreation Professionals. Journal of Park \& Recreation Administration, 23(3), 45-62.

Hurd, AR., Elkins, DJ, Beggs, BA. (2014). Using competencies to assess entry-level knowledge of students graduating from parks and recreation academic programs. Schole: A Journal of Leisure Studies and Recreation Education, 29(1), 51-59.

Hurd, AR., McLean, DD. (2004). An analysis of the perceived competencies of CEOs in public park and recreation agencies. Managing Leisure, 9(2), 96-110.

Jones, I., Brown L., Holloway I. (2013). Qualitative research in sport and physical activity. London: Sage Publications.

Miles, MB., Huberman, AM. (1994). Qualitative Data Analysis: An Expanded Sourcebook. Thousand Oaks: Sage Publications.

Milli Eğitim Bakanlığı (MEB), (2011). Personel Genel Müdürlüğü Ögretmenlik Iç̧in Başvuru ve Atama Kllavuzu (Haziran 2011). Available from:
http://personel.meb.gov.tr/kilavuzlar/\%C3\%9 6\%C4\%9Fretmenlik\%20\%C4\%B0\%C3\%A7 in $\% 20 \mathrm{Ba} \% \mathrm{C} 5 \% 9$ Fvuru $\% 20 \mathrm{ve} \% 20 \mathrm{Atama} \% 2$ 0K\%C4\%B1lavuzu\%20(2011\%20Haziran).p df

OSYM, (2020). 2020 Yüksekögrretim Programları ve Kontenjan Kllavuzu. Available from: https://www.osym.gov.tr/TR,19431/2020yuksekogretim-kurumlari-sinavi-yksyuksekogretim-programlari-ve-kontenjanlarikilavuzu.html.

Republic of Turkey Ministry of Youth and Sports, (2018). T.C. Gençlik ve spor bakanliğl spor genel müdürlügü sözleşmeli spor uzmanı ve sözleşmeli antrenör alımı duyurusu Available from: https://gsb.gov.tr/Duyuru/137084/tcgenclik-ve-spor-bakanligi-spor-genelmudurlugu-sozlesmeli-spor-uzmani-vesozlesmeli-antrenor-alimi-duyurusu.aspx

SETA Analysis. (2010). Türkiye'de istihdam durumu: Genel eğilimler [Employment situation in Turkey: General trends]. [cited 2016 Sep 20]. Available from: http://arsiv.setav.org/Ups/dosya/35324.pdf

Schneider, RC., Stier, Jr WF, Kampf, S, Haines, SG, Wilding, G. (2006). Characteristics, attributes, and competencies sought in new hires by campus recreation directors. Recreational Sports Journal, 30(2), 142-153.

Şimşek, KY. (2013). The commercial recreation and service quality in malls. Pamukkale Journal of Sport Sciences, 4(3), 53-75.

Şimşek, KY. (2018). Ticari Rekreasyon Ankara: Detay Yayıncılık.

Torkildsen G. (2005). Leisure and recreation management. Abingdon: Psychology Press

Tripolitsioti, A, Moudakis, K, Konstantinakos, P, Theodorikakos, P. (2007). The management competencies of the directors of youth centres and indoor facilities in the municipalities. Biology of Exercise, 3, 47-57.

Tsitskari, E, Goudas, M, Tsalouchou, E, Michalopoulou, M. (2017). Employers' Expectations of the Employability Skills Needed in the Sport and Recreation Environment. Journal of Hospitality, Leisure, Sport \& Tourism Education, 20(1), 1-9.

Yıldırım, A., Şimşek, H. (2016). Sosyal Bilimlerde Nitel Araştırma Yöntemleri. Ankara: Seçkin Yayıncılık. 